\title{
Differential sexual network connectivity offers a parsimonious explanation for population-level variations in the prevalence of bacterial vaginosis: a data- driven, model-supported hypothesis
}

\author{
Chris R. Kenyon ${ }^{1 *}$ D, Wim Delva $2,3,4,5,6$ and Rebecca M. Brotman ${ }^{7}$
}

\begin{abstract}
Background: The prevalence of bacterial vaginosis (BV) and vaginal microbiota types varies dramatically between different populations around the world. Understanding what underpins these differences is important, as highdiversity microbiotas associated with BV are implicated in adverse pregnancy outcomes and enhanced susceptibility to and transmission of sexually transmitted infections.

Main text: We hypothesize that these variations in the vaginal microbiota can, in part, be explained by variations in the connectivity of sexual networks. We argue: 1) Couple-level data suggest that BV-associated bacteria can be sexually transmitted and hence high sexual network connectivity would be expected to promote the spread of BVassociated bacteria. Epidemiological studies have found positive associations between indicators of network connectivity and the prevalence of BV; 2) The relationship between BV prevalence and STI incidence/prevalence can be parsimoniously explained by differential network connectivity; 3) Studies from other mammals are generally supportive of the association between network connectivity and high-diversity vaginal microbiota.
\end{abstract}

Conclusion: To test this hypothesis, we propose a combination of empirical and simulation-based study designs.

Keywords: Bacterial vaginosis, Microbiome, Sexual network connectivity, Concurrency, STI, HIV

\section{Background}

Over 17 studies from around the world have established that women's vaginal microbiota (VMB) can be classified into one of 3 to 9 clusters or community state types (CSTs) [1-3]. The most commonly referenced typing system is that developed by Ravel et al. in 2011 [4]. This schema describes 5 CSTs of which four CSTs were respectively dominated by 4 different Lactobacillus species - L. crispatus, L gasseri, L. iners and L. jensenii (Fig. 1). The fifth CST was characterized by a paucity of Lactobacillus spp. and an abundance of a highly diverse polymicrobial community of facultative anaerobic BV-associated

\footnotetext{
* Correspondence: ckenyon@itg.be

'STI Unit, Institute of Tropical Medicine, Nationalestraat 155, 2000 Antwerp, Belgium

Full list of author information is available at the end of the article
}

bacteria (BVAB), including Gardnerella vaginalis, Atopobium vaginae, Clostridiales spp., Megasphaera spp. and Leptotrichia/Sneathia spp. [1,5]. This CST (which can be split into two different CSTs [6]) corresponds closely with bacterial vaginosis (BV) as defined by Nugent's scoring system, as well as $\mathrm{pH}$, and we refer to it here as the BV-VMB. Several longitudinal VMB studies have concluded that the VMB can be relatively stable over time $[1$, $7,8]$. In a minority of women and particularly those with $\mathrm{BV}-\mathrm{VMB}$, the community composition of the VMB can be fairly dynamic $[1,7]$.

There is little consensus as to why the proportion of reproductive-age women with particular CSTs, and in particular those with BV-VMB, varies so dramatically between different populations [1]. Some have postulated that genetic differences between populations (such as 


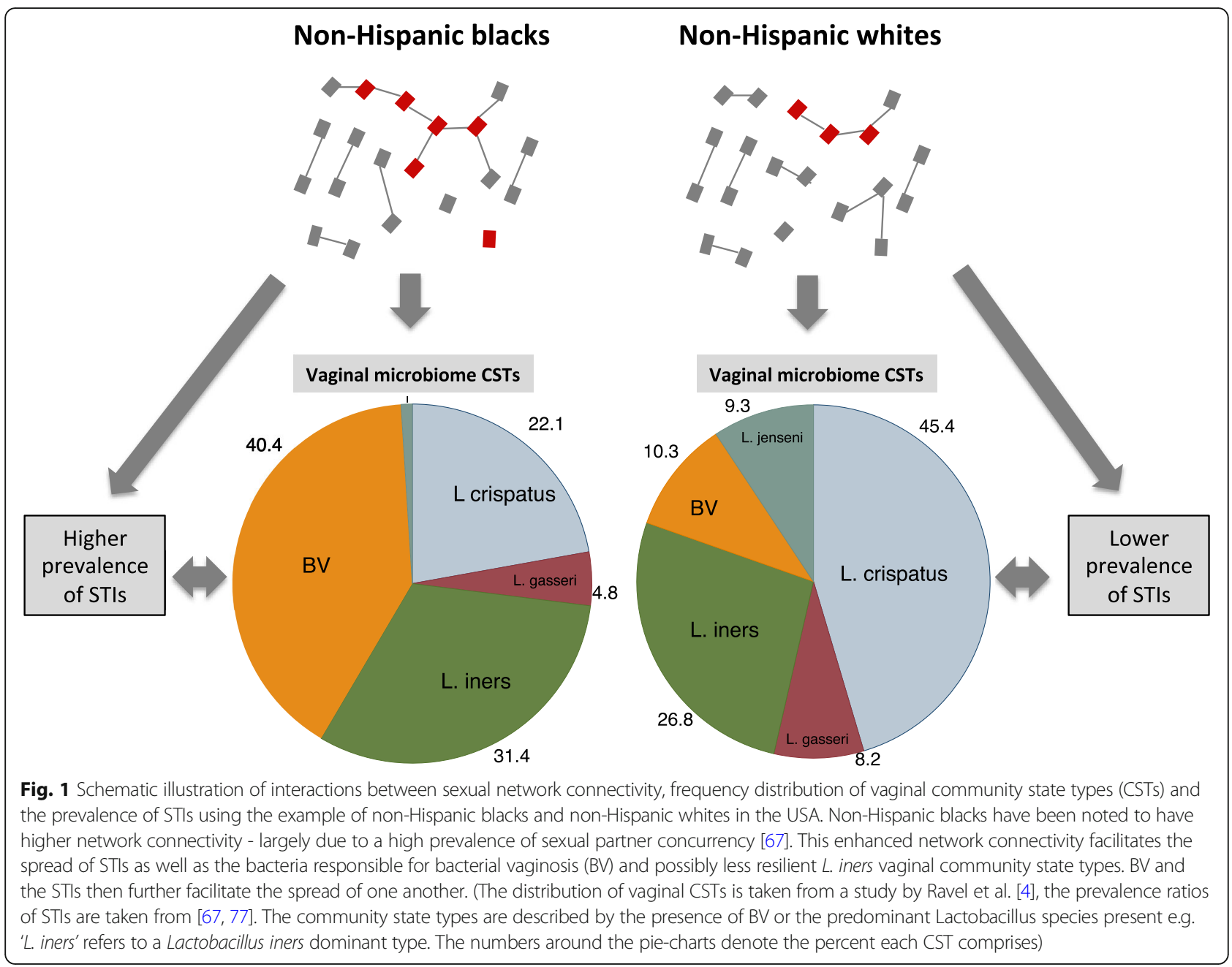

differences in innate and adaptive immune systems, the composition and quantity of vaginal secretions, and ligands on epithelial cell surfaces $[4,9])$ may be responsible. Others have argued that the prevalence of practices known to influence the VMB may be responsible: including use of vaginal douching, nutrition, smoking, personal hygiene, methods of birth control, and sexual behaviors [10-12].

Both BV and some L. iners-dominated VMBs have been associated with various adverse outcomes, including enhanced susceptibility to STIs such as HIV, enhanced transmission of HIV, pelvic inflammatory disease and a range of adverse pregnancy outcomes [13-15]. One meta-analysis found that BV-VMB increased the risk of HIV acquisition by $60 \%$ (relative risk $95 \%$ CI $1.2-$ 2.1) [16]. In populations where the prevalence of $\mathrm{BV}$ is over $30 \%$, this may translate into $15 \%$ of HIV infections being attributable to BV-VMB [16]. Similar lines of reasoning suggest that BV-VMB may explain a considerable proportion of the differential spread of other STIs between different populations [17-23].
We hypothesize that variations in sexual network connectivity may be at least partially responsible for variations in the prevalence of BV-VMB between different populations, and below we present three types of evidence in support of this thesis:

\section{Individual and couple-level data}

Individual and couple-level data suggest that BVAB can be sexually transmitted. Multiple studies have found an association between BV and a number of individual-level sexual risk factors amongst women including: i) a higher number of lifetime sexual partners [24]; ii) retaining the same sexual partner after a diagnosis of BV $[25,26]$; iii) a high frequency of vaginal intercourse [27]; iv) self-identification as sex workers [28, 29]; v) anal or receptive oral sex $[30,31]$; vi) sharing sex toys between women who have sex with women [32]. Male circumcision has been shown in a randomized controlled trial to result in a $50 \%$ lower risk of BV for partners of circumcised males [33]. Circumcision was also associated with a reduction in a wide range of anaerobes in the coronal 
Table 1 Correlation of bacterial species between vagina and penile skin and male urethra from couples with bacterial vaginosis and couples without bacterial vaginosis in cross sectional study by Zozaya et al. [39] Only the top 13 most correlated species are shown

\begin{tabular}{|c|c|c|}
\hline & Vagina-Penile Skin & Vagina-Male Urethra \\
\hline & $\operatorname{Rho}^{a}$ & Rho $^{a}$ \\
\hline \multicolumn{3}{|c|}{ Couples with BV $(n=65)$} \\
\hline Megasphaera2 & 0.549 & 0.085 \\
\hline Pv.123-f2-42 & 0.537 & 0.584 \\
\hline Pv.123-f-110 & 0.482 & 0.448 \\
\hline BVAB1 & 0.477 & 0.153 \\
\hline P.bivia & 0.422 & 0.510 \\
\hline Prevotella & 0.421 & 0.402 \\
\hline Gardnerella & 0.419 & 0.324 \\
\hline Aerococcus & 0.413 & 0.421 \\
\hline Pv.123-b-95 & 0.411 & 0.239 \\
\hline L.iners & 0.399 & 0.215 \\
\hline Porphyromonas & 0.399 & 0.105 \\
\hline Sneathia & 0.376 & 0.258 \\
\hline Leptotrichia & 0.371 & 0.376 \\
\hline \multicolumn{3}{|c|}{ Couples without BV $(n=31)$} \\
\hline Pv.123-f-82 & 0.504 & -0.033 \\
\hline Dialister & 0.443 & 0.240 \\
\hline L.crispatus & 0.391 & -0.084 \\
\hline L.jensenii & 0.384 & -0.259 \\
\hline Lactobacillus sp. & 0.327 & 0.284 \\
\hline Pv.123-b-46 & 0.280 & 0.379 \\
\hline Streptococcus & 0.221 & 0.179 \\
\hline U.urealyticum & 0.156 & -0.071 \\
\hline L.helveticus & 0.142 & 0.223 \\
\hline L.gasseri & 0.125 & -0.133 \\
\hline Peptoniphilus & 0.049 & -0.023 \\
\hline Gardnerella & 0.034 & -0.146 \\
\hline L.iners & -0.020 & 0.043 \\
\hline
\end{tabular}

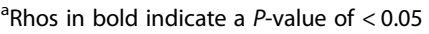

sulcus including a number of BVAB [33, 34]. Consistent condom use has been shown in a meta-analysis to be associated with a reduced odds for BV [24] and several, but not all studies, have found that inconsistent or no condom use is a risk factor for recurrent BV [24, 27, 35]. These findings suggest that BV can be sexually transmitted. Other non-sexual epidemiologic risk factors for BV include: i) lack of hormonal contraception ii) cigarette smoking, iii) douching [13] (Table 1).

Couple studies have found high rates of concordance (up to 100\%) for various BVAB (including biofilm forming $G$. vaginalis [36]) in women's VMB and the coronal sulci/distal urethras of their male partners [36-41] or the vaginas of their female partners [42]. A study of the genital microbiomes of 165 men and their partners in Rakai, Uganda found that the penile microbiomes could be segregated into two main groups - a BV and a non-BV-type group [43]. The BV-type group had a higher prevalence and abundance of BV associated bacteria. The female partners of this group were also more likely to have BV [43] as assessed by Nugent's scoring (the women in this study did not have their vaginal microbiomes characterized molecularly). Two studies that simultaneously characterized the genital microbiomes of women and their male partners found a strong intra-couple correlation for the presence or absence of individual bacterial species [39, 44]. In both studies, concentrations of BVAB were low or undetectable in women without BV and their partners but abundant and concordant at a species level for women with $\mathrm{BV}$ and their partners coronal sulci (and to a lesser extent urethra) [39, 44]. Other studies have established a high degree of concordance of oligotype and phenotype (such a biofilm forming or not) of G. vaginalis and other BVAB between monogamous partners [36, 45, 46]. In one of these studies, for example, all women with BV had evidence of a biofilm- forming G. vaginalis vaginal infection as did all their male partners in their urine [36]. Women who have sex with women have also been shown to have a high degree of concordance for BV status and this has been linked to practices that transmit vaginal fluid between women $[47,48]$.

STIs are transmitted along sexual networks, and as a result, the amount of connectivity between individuals in the network determines the speed and extent of STI spread in the network [49-51]. Network connectivity is a complex concept that can be characterized by a multi-dimensional array of metrics, including the number of partners per unit time, prevalence of concurrent partnering, size of core groups, type of sex, size of sexual network, length of gaps between partnerships, degree and type of homophily and relations between core and non-core groups [50, 52-57]. We will confine our further consideration of network connectivity to number of partners per unit time and partner concurrency (partnerships overlapping in time). Both of these variables have clear definitions, have multiple prevalence estimates from around the world and have been found to be risk factors for most major STIs, including BV at the individual level [24, 52, 58-61]. We acknowledge however that these variables are measures of local sexual networks. Future work could benefit from incorporating better measures of global sexual network connectivity such as the size of the forward reachable set. Since sexual network connectivity is a population-level property, ecological studies are also necessary to explore the possible 
explanations for variations in STI prevalence [50, 62]. Although not all studies have reached this conclusion, $[63,64]$ studies have generally found a positive association between STI prevalence and the prevalence of partner concurrency and/or numbers of partners per unit time [50, 52, 58, 65-67].

If $\mathrm{BVAB}$ are sexually transmitted then the various ways whereby enhanced network connectivity has been shown to enhance the transmission of various STIs could also promote the spread of BVAB [58]. This is illustrated in Fig. 2 and Additional file 1, which contrast the transmissibility of BVAB in high and low connectivity populations. In Fig. 2, both networks commence with woman 'A' having a BV-VMB (red). In the high connectivity network, the BVAB can be transmitted to her partner ' $\mathrm{B}$ ' who can then transmit them to the other women he is having sex with and the BV-VMB can thereby spread through the population. In the low connectivity network, the BVAB are trapped in the 'A-B' relationship until it breaks up at $\mathrm{T}_{3}$ when both 'A' and 'B' can transmit the BVAB to their new partners.

Enhanced network connectivity may play a particularly important role in facilitating the spread of the BV-associated G. vaginalis and T. vaginalis, because of their relatively short periods of colonization in men [68].
T. vaginalis colonizes men for only 6 weeks (and women for 60 weeks) [69, 70]. This gender gap in colonization-duration means that $T$. vaginalis would go extinct in a serial monogamous population with at least 7 weeks between consecutive partners of men [66]. Concurrency enables $T$. vaginalis to bypass this bottleneck and thereby could facilitate the spread of $T$. vaginalis and indirectly BV (because $T$. vaginalis predisposes to BV [71]). Similarly, G. vaginalis - one of the likely driver species of BV [72, 73] - has been shown to be well adapted to long-term colonization of the high glycogen vaginal environment [74] but poorly suited to long-term urethral colonization in men [74]. G. vaginalis thus colonizes men for under 3 months but persists long term in women $[36,75]$. One study, for example, found an identical strain of biofilm forming G. vaginalis persisting in one woman's vagina for 15 years [36]. If the BVAB (or at least a number of the keystone species responsible for BV) have a duration of colonization in the male that is as short as that of G. vaginalis, then this would result in a break of transmission of BVAB in populations with serial monogamy and gaps of a few months between sexual relationships. The illustration in Fig. 2 would then need to be adapted as 'B' would no longer be able to transmit the BVAB to his new partner at $\mathrm{T}_{3}$ if the time

\section{High connectivity}

\section{Low connectivity}

$\mathrm{T}_{1}$

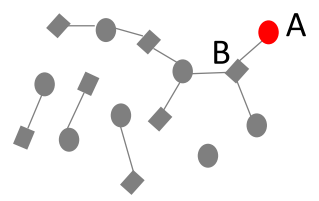

$\mathrm{T}_{2}$

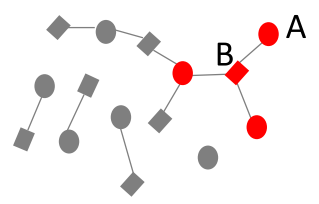

$\mathrm{T}_{3}$

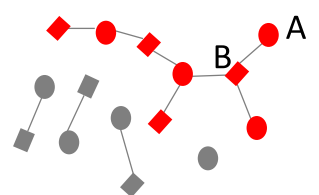

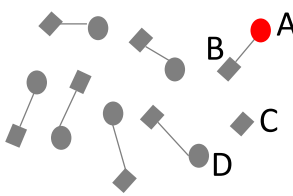
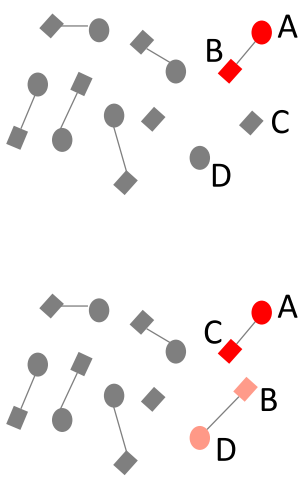

Fig. 2 Schematic illustration of how high sexual network connectivity can enhance transmission of bacterial vaginosis associated bacteria (BVAB depicted in red). In the low connectivity network (right), the BVAB are trapped in the A-B relationship until this breaks up when woman A can transmit the BVAB to her new partner (C). Man B may then also transmit BVAB to his new partner (D) but if the gap between his old and new partner exceeds the duration of penile colonization for BVAB (time between $T_{2}$ and $T_{3}$ ) then he will not transmit to his new partner. In the high connectivity network (left), the BVAB does not need to wait for the A-B partnership to end and can, without impediment, spread to other individuals connected via sexual partnerships (Squares-men, Circles-women, Red/Gray nodes-BVAB-/non-BVAB -containing genital microbiome, Gray lines-sexual partnership active on first day of the month; see text for further details) 
gap since his previous relationship was long enough to have removed the BVAB from his penile microbiome.

\section{An individual-based network model of BV transmission}

To demonstrate the interacting effects of higher sexual network connectivity and a shorter duration of colonization in men more explicitly, we developed a simple, didactic individual-based model representing two adjacent but entirely separate communities (see Additional file 1: NetworkModelDescription for a detailed description of the model). In the first community only serially monogamous relationships can be formed. In the second, both men and women remain available to form new relationships, regardless of the number of relationships they are already engaged in. In both communities, the duration of BVAB colonization is set to a fixed period of 6 weeks in men and 60 weeks in women. Additional file 2: NetworkMovie shows model output over 10 years with populations of 250 people in each community. In the community where concurrent relationships were allowed, the prevalence of partner concurrency varied between 2 and $11 \%$ over the 10-year simulation period, and by the end of it, $42 \%$ more relationships had been formed, compared to the community with lower network connectivity. The prevalence of BV-VMB plateaued around $55 \%$ in the high connectivity network and around $15 \%$ in the low connectivity network (a relative difference of 267\%). This is an example based in heterosexual couplings and certainly future models should include partnerships between women as well.

\section{Epidemiological studies confirm that concurrency and partner number are risk factors for BV}

Epidemiological studies have shown number of partners per unit time to be a risk factor for BV-VMB [24, 76, 77]. Partner concurrency has also been shown to be an independent risk factor for BV in a longitudinal study of 3620 women followed up quarterly for 5 visits [58]. In the Rakai study mentioned above, men with extramarital partners were also found to be more likely to have the BV-type penile microbiome than men with no extramarital partners [43]. Finally, an ecological study found associations at the level of countries between the prevalence of male concurrency and the prevalence of BV among women [78]. The same association was found at the level of ethnic groups within countries [78].

\section{Network connectivity is a parsimonious explanation for the association between the prevalence of BV and STIs}

It has been argued that certain racial groups such as 'black populations' [9] tend to have a higher prevalence of $\mathrm{BV}$ and that this is due to biological differences in susceptibility to BV $[4,9,79]$. The available evidence, however, suggests that populations (irrespective of race) with high network connectivity have a higher BV prevalence. (i) Black populations with low risk behavior as established by low prevalence of HIV and other STIs have low prevalences of BV [80, 81]. (ii) Populations with high network connectivity (as deduced by high STI prevalences) have high BV prevalences regardless of ethnicity. This has been most clearly established in sex workers where sex workers from all ethnic groups with available data have high BV prevalences [2, 28, 29]. BV prevalences have also been found to vary between non-black ethnic/racial groups within Canada, Peru, China and Spain [80]. In the case of Canada and Peru, the high BV-prevalence ethnic groups were also found to have higher prevalences of other STIs suggesting a common risk factor may be responsible [80]. (iii) The available evidence suggests that prior to sexual debut, there are no differences in VMB between ethnic groups but that differences only emerge post debut [82, 83]. (iv) In a longitudinal study, white women with black partners had the same BV prevalence as black women [84] and black women with white partners had the same BV prevalence as white women (C Kenyon's unpublished data). (v) The VMBs from all racial/ethnic groups profiled thus far include all the major CSTs. It is merely the proportionate mix of CSTs that varies between ethnic groups $[1,85]$. (vi) We have been unable to find any published studies that have established evidence of genetic differences in susceptibility to particular VMBs by race/ethnic group.

Populations with a higher prevalence of BV also tend to have a higher prevalence of other STIs [65]. This association has been shown between BV and HIV prevalence at the level of world regions [80], countries [65] and ethnic groups within countries (Fig. 1) [80]. These positive associations between STIs and BV could be due to a common underlying risk factor (such as network connectivity [65]) Alternatively, they could be explained by these STIs enhancing the probability of transition to BV [17]. However, this explanation begs the question, why did these populations have higher STI prevalences? A possible answer is that they have poorer STI treatment services [86]. The correlation between STI prevalence and quality of STI services is, however, weak or absent [87]. Furthermore, this does not explain the strong correlation between the incurable STI, herpes simplex virus-2 (HSV-2), and BV and other STIs [88, 89]. These considerations lead us to predict that the most parsimonious explanation for why the prevalence of BV and various STIs is higher in certain populations than others is that these populations have more densely connected sexual networks. High network connectivity would be expected to not only directly facilitate the spread of BVAB and other STIs, but also to do so indirectly via the 
positive feedback resulting from BV and STIs enhancing the spread of one another. BV for example has been shown to enhance susceptibility to chlamydia [17, 21], gonorrhoea [17], HIV [23, 90, 91], HSV-2 [18, 19] and T. vaginalis $[17,21,22]$. HSV-2 and T. vaginalis have in turn been found to increase the risk for development of BV and acquisition of other STIs [17, 20, 21, 23].

\section{Data from animal studies}

Results from vaginal microbiome profiling in other animals are compatible with the hypothesis that differences in sexual network connectivity influence vaginal microbiomes. A study that compared the sympatric mice, Peromyscus californius and Peromyscus maniculatus found that the socially and genetically promiscuous $P$. maniculatus had greater vaginal microbiome diversity (a key feature of a BV-VMB) than the monogamous $P$. californius [92]. Likewise a study that compared the vaginal microbiomes of 9 primate species with different mating behaviors found that vaginal microbial diversity was strongly correlated with host-specific socioecologic factors such as female and male promiscuity [93]. Unlike the gut microbiome the vaginal microbiome showed little congruence with host phylogeny or diet [93]. The authors concluded that differences in sexual behavior were key determinants of the degree of vaginal microbial diversity.

\section{Empirical and simulation-based hypothesis tests}

Testing the network-connectivity-VMB hypothesis would ideally involve longitudinal studies that follow up sympatric sub-populations with high and low STI prevalence from the time of sexual debut. Critically these studies should characterize the vaginal and penile microbiomes of sexual partners at frequent intervals. This, combined with detailed behavioral data, should enable researchers to ascertain if differences in network connectivity are responsible for the differential spread of BVAB in the high and low STI prevalence populations. The longitudinal study design should also provide better insights into the interactions between sexual behaviour, genital microbiomes and STIs. The importance of these longitudinal couple studies for the BV-network connectivity hypothesis cannot be overstated. We have shown evidence of a strong correlation between penile skin microbiota and the partner's VMB. Longitudinal studies are however required to establish that these penile microbiota can be sexually transmitted to the man's next partner and result in changes in her VMB.

In addition to empirical research, simulation-based study designs would also be useful to test aspects of the hypothesis presented here. Previous modeling studies have found that relatively small increases in network connectivity can lead to non-linear increases in HIV/ STI spread [53]. If this applies to BV as well, then more connected sexual networks would be expected to facilitate the rapid spread of BVAB and various other STIs soon after sexual debut. Our own individual-based model of BVAB transmission provides a fitting illustration of the strong, non-linear effect of higher network connectivity, even in the absence of other STIs. The addition of a few key features could turn this didactic tool into a rigorous framework that unifies relevant knowledge of the microbiology, epidemiology and sociology of BV and other STI co-infections. In line with current insights from molecular microbiology, vaginal and penile microbiomes should be classified into at least five CSTs [43]. Furthermore, interactions with various STI co-infections - most notably chlamydia, gonorrhoea, T. vaginalis, HSV-2 and HIV - should be modelled explicitly, and other non-infectious causal factors (such as douching, smoking, diet) on the pathway to develop BV should be included as well. Lastly, the model should allow for more heterogeneity in sexual activity levels, as well as more structure in the network (for example, a non-random age-mixing pattern, and clustering of a high-risk core group within the network, and same sex partnerships). Besides the obvious advantages of being relatively fast and inexpensive, simulation studies can quantify the effect of uncertainty surrounding behavioral and biological parameters on the main outcomes measures.

If confirmed by empirical and simulated data, the network connectivity approach would offer a new paradigm for conceptualizing how differences in $\mathrm{VMB}$ emerge. If the proportion of a population that has BV is a population-level-property that is partially determined by network connectivity, then this introduces new options for prevention of $\mathrm{BV}$ and BV-associated adverse health outcomes such as adverse pregnancy outcomes and transmission of other STIs including HIV. It suggests that interventions that have been shown to reduce network connectivity may result in reductions in the prevalence of these VMBs. Because BV-VMBs may be responsible for a large proportion of the population attributable fraction of HIV and other STIs [16] and the spread of these STIs is also directly enhanced by network connectivity, small reductions in connectivity could translate into large declines in STI incidence. Uganda's 'Zero Grazing' campaign [94] and similar processes elsewhere in Africa [95], which resulted in dramatic declines in side-partners and hence network connectivity, could be viewed as providing guidance for this approach. A better appreciation for the network connectivity would also help us unravel the disparities between ethnic groups that we see in $\mathrm{BV}$, STIs and reproductive outcomes. 


\section{Additional files}

Additional file 1: A text document detailing the construction of the Netlogo model of BV transmission. (PDF $63 \mathrm{~kb}$ )

Additional file 2: A movie file illustrating the main findings of the Netlogo model of BV transmission. (MP4 60657 kb)

Additional file 3: The Netlogo model of BV transmission. (NLOGO $30 \mathrm{~kb}$ )

\section{Abbreviations}

BV: Bacterial Vaginosis; CST: Community State Type; VMB: Vaginal Microbiome

\section{Acknowledgements}

We would like to thank Tania Crucitti, Leigh Johnson and discussants at the University of Cape Town Public Health Seminar Series for helpful comments on an earlier draft of the paper.

\section{Funding}

\section{Availability of data and materials}

The model of BV transmission including all code used is available in Additional file 3 .

\section{Authors' contributions}

CK conceptualized the paper. WD created the model. CK, WD and RB played a role in writing, editing and approving the final version.

\section{Ethics approval and consent to participate}

Not applicable.

\section{Consent for publication}

Not applicable.

\section{Competing interests}

The authors declare that they have no competing interests.

\section{Publisher's Note}

Springer Nature remains neutral with regard to jurisdictional claims in published maps and institutional affiliations.

\section{Author details}

ISTI Unit, Institute of Tropical Medicine, Nationalestraat 155, 2000 Antwerp, Belgium. ${ }^{2}$ The South African DST-NRF Centre of Excellence in Epidemiological, Modelling and Analysis (SACEMA), Stellenbosch, South Africa. ${ }^{3}$ Department of Global Health, Faculty of Medicine and Health Sciences, Stellenbosch University, Stellenbosch, South Africa. ${ }^{4}$ International Centre for Reproductive Health, Ghent University, Ghent, Belgium. ${ }^{5}$ Center for Statistics, Hasselt University, Diepenbeek, Belgium. ${ }^{6}$ Rega Institute for Medical Research, KU Leuven, Leuven, Belgium. ${ }^{7}$ Department of Epidemiology and Public Health, Institute for Genome Sciences, University of Maryland School of Medicine, Ghent, Belgium.

Received: 18 June 2018 Accepted: 20 December 2018 Published online: 10 January 2019

\section{References}

1. van de Wijgert JH, Borgdorff H, Verhelst $\mathrm{R}$, Crucitti T, Francis S, Verstraelen $H_{\text {, }}$ et al. The vaginal microbiota: what have we learned after a decade of molecular characterization? PLoS One. 2014;9(8):e105998. https://doi.org/10. 1371/journal.pone.0105998 PubMed PMID: 25148517; PubMed Central PMCID: PMCPMC4141851.

2. Jespers V, Crucitti T, Menten J, Verhelst R, Mwaura M, Mandaliya K, et al. Prevalence and correlates of bacterial vaginosis in different sub-populations of women in sub-Saharan Africa: a cross-sectional study. PLoS One. 2014;9(10):e109670. https://doi.org/10.1371/journal. pone.0109670 Epub 2014/10/08. PubMed PMID: 25289640; PubMed Central PMCID: PMCPMC4188821.

3. Lennard K, Dabee S, Barnabas SL, Havyarimana E, Blakney A, Jaumdally SZ, et al. Microbial composition predicts genital tract inflammation and persistent bacterial vaginosis in adolescent South African women. Infect Immun. 2017. https://doi.org/10.1128//Al.00410-17 Epub 2017/10/19. PubMed PMID: 29038128.

4. Ravel J, Gajer P, Abdo Z, Schneider GM, Koenig SS, McCulle SL, et al. Vaginal microbiome of reproductive-age women. Proc Natl Acad Sci U S A. 2011; 108(Suppl 1):4680-7. https://doi.org/10.1073/pnas.1002611107 Epub 2010/ 06/11. PubMed PMID: 20534435.

5. Fredricks DN, Fiedler TL, Marrazzo JM. Molecular identification of bacteria associated with bacterial vaginosis. N Engl J Med. 2005;353(18):1899-911. https://doi.org/10.1056/NEJMoa043802 Epub 2005/11/04. PubMed PMID: 16267321.

6. Gajer P, Brotman RM, Bai G, Sakamoto J, Schutte UM, Zhong X, et al. Temporal dynamics of the human vaginal microbiota. Sci Transl Med. 2012; 4(132):132ra52. https://doi.org/10.1126/scitranslmed.3003605 Epub 2012/05/ 04. 4/132/132ra52. PubMed PMID: 22553250.

7. Wertz J, Isaacs-Cosgrove N, Holzman C, Marsh TL. Temporal Shifts in Microbial Communities in Nonpregnant African-American Women with and without Bacterial Vaginosis. Interdiscip Perspect Infect Dis. 2008;2008:181253. https://doi.org/10.1155/2008/181253 Epub 2008/01/01. PubMed PMID: 19277101; PubMed Central PMCID: PMCPMC2648625.

8. Santiago GL, Cools P, Verstraelen H, Trog M, Missine G, El Aila N, et al. Longitudinal study of the dynamics of vaginal microflora during two consecutive menstrual cycles. PLoS One. 2011;6(11):e28180. https://doi.org/ 10.1371/journal.pone.0028180 Epub 2011/12/06. PubMed PMID: 22140538; PubMed Central PMCID: PMCPMC3227645.

9. Buve A, Jespers V, Crucitti T, Fichorova RN. The vaginal microbiota and susceptibility to HIV. AIDS. 2014;28(16):2333-44 PubMed PMID: 25389548.

10. Schwebke JR. New concepts in the etiology of bacterial vaginosis. Curr Infect Dis Rep. 2009;11(2):143-7 Epub 2009/02/26. PubMed PMID: 19239805.

11. Bradshaw CS, Brotman RM. Making inroads into improving treatment of bacterial vaginosis - striving for long-term cure. BMC Infect Dis. 2015;15:292. https://doi.org/10.1186/s12879-015-1027-4 Epub 2015/07/30. PubMed PMID: 26219949; PubMed Central PMCID: PMC4518586.

12. Callahan BJ, DiGiulio DB, Goltsman DSA, Sun CL, Costello EK, Jeganathan $P$, et al. Replication and refinement of a vaginal microbial signature of preterm birth in two racially distinct cohorts of US women. Proc Natl Acad Sci U S A. 2017;114(37):9966-71. https://doi.org/10.1073/pnas.1705899114 Epub 2017/ 08/30. PubMed PMID: 28847941; PubMed Central PMCID: PMCPMC5604014.

13. Bautista CT, Wurapa E, Sateren WB, Morris S, Hollingsworth B, Sanchez JL. Bacterial vaginosis: a synthesis of the literature on etiology, prevalence, risk factors, and relationship with chlamydia and gonorrhea infections. Mil Med Res. 2016;3:4. https://doi.org/10.1186/s40779-016-0074-5 Epub 2016/02/16. PubMed PMID: 26877884; PubMed Central PMCID: PMCPMC4752809.

14. Petrova MI, Reid G, Vaneechoutte M, Lebeer S. Lactobacillus iners: friend or foe? Trends Microbiol. 2017;25(3):182-91. https://doi.org/10.1016/j.tim.2016. 11.007 Epub 2016/12/05. PubMed PMID: 27914761

15. Vaneechoutte M. Lactobacillus iners, the unusual suspect. Res Microbiol. 2017. https://doi.org/10.1016/j.resmic.2017.09.003 Epub 2017/09/28. PubMed PMID: 28951208

16. Atashili J, Poole C, Ndumbe PM, Adimora AA, Smith JS. Bacterial vaginosis and HIV acquisition: a meta-analysis of published studies. AIDS. 2008:22(12): 1493-501. https://doi.org/10.1097/QAD.0b013e3283021a37 Epub 2008/07/ 11. PubMed PMID: 18614873; PubMed Central PMCID: PMCPMC2788489.

17. Brotman RM, Klebanoff MA, Nansel TR, Kai FY, Andrews WW, Zhang J, et al. Bacterial vaginosis assessed by gram stain and diminished colonization resistance to incident gonococcal, chlamydial, and trichomonal genital infection. J Infect Dis. 2010;202(12):1907-15.

18. Cherpes TL, Meyn LA, Krohn MA, Hillier SL. Risk factors for infection with herpes simplex virus type 2: role of smoking, douching, uncircumcised males, and vaginal flora. Sex Transm Dis. 2003;30(5):405-10 PubMed PMID: 12916131

19. Cherpes TL, Meyn LA, Krohn MA, Lurie JG, Hillier SL. Association between acquisition of herpes simplex virus type 2 in women and bacterial vaginosis. Clin Infect Dis. 2003;37(3):319-25. https://doi.org/10.1086/375819 Epub 2003/07/29. PubMed PMID: 12884154

20. Esber A, Vicetti Miguel RD, Cherpes TL, Klebanoff MA, Gallo MF, Turner AN. Risk of bacterial vaginosis among women with herpes simplex virus type 2 infection: a systematic review and meta-analysis. J Infect Dis. 2015:212(1):817. https://doi.org/10.1093/infdis/jiv017 PubMed PMID: 25589333.

21. Kaul R, Nagelkerke NJ, Kimani J, Ngugi E, Bwayo JJ, Macdonald KS, et al. Prevalent herpes simplex virus type 2 infection is associated with altered 
vaginal flora and an increased susceptibility to multiple sexually transmitted infections. J Infect Dis. 2007;196(11):1692-7. https://doi.org/10.1086/522006 PubMed PMID: 18008255.

22. Rathod SD, Krupp K, Klausner JD, Arun A, Reingold AL, Madhivanan P. Bacterial vaginosis and risk for Trichomonas vaginalis infection: a longitudinal analysis. Sex Transm Dis. 2011;38(9):882-6. https://doi.org/10. 1097/OLQ.0b013e31821f91a1 Epub 2011/08/17. PubMed PMID: 21844747; PubMed Central PMCID: PMCPMC3156984.

23. Rottingen JA, Cameron DW, Garnett GP. A systematic review of the epidemiologic interactions between classic sexually transmitted diseases and HIV: how much really is known? Sex Transm Dis. 2001;28(10):579-97 PubMed PMID: 11689757.

24. Fethers KA, Fairley CK, Hocking JS, Gurrin LC, Bradshaw CS. Sexual risk factors and bacterial vaginosis: a systematic review and meta-analysis. Clin Infect Dis. 2008:47(11):1426.

25. Bradshaw CS, Vodstrcil LA, Hocking JS, Law M, Pirotta M, Garland SM, et al. Recurrence of Bacterial Vaginosis Is Significantly Associated With Posttreatment Sexual Activities and Hormonal Contraceptive Use. Clin Infect Dis. 2013;56(6):777-86. https://doi.org/10.1093/Cid/Cis1030 PubMed PMID: WOS:000315630800009.

26. Marrazzo JM. Editorial commentary: sexual networks, sex hormones, and recurrent bacterial vaginosis: not such strange bedfellows. Clin Infect Dis 2013;56(6):787-9. https://doi.org/10.1093/cid/cis1034 Epub 2012/12/18. PubMed PMID: 23243177.

27. Schwebke JR, Desmond R. Risk factors for bacterial vaginosis in women at high risk for sexually transmitted diseases. Sex Transm Dis. 2005;32(11):6548 Epub 2005/10/29. PubMed PMID: 16254538.

28. Uma S, Balakrishnan P, Murugavel KG, Srikrishnan AK, Kumarasamy N, Cecelia JA, et al. Bacterial vaginosis in female sex workers in Chennai. India Sex Health. 2005;2(4):261-2 Epub 2006/01/13. PubMed PMID: 16402677.

29. Venegas $G$, Boggiano G, Castro E. Prevalence of bacterial vaginosis in Chilean sex workers. Rev Panam Salud Publica. 2011;30(1):46-50 Epub 2011/ 12/14. PubMed PMID: 22159650.

30. Brotman RM, Ravel J, Cone RA, Zenilman JM. Rapid fluctuation of the vaginal microbiota measured by Gram stain analysis. Sex Transm Infect. 2010;86(4):297-302. https://doi.org/10.1136/sti.2009.040592 Epub 2010/07/ 28. PubMed PMID: 20660593; PubMed Central PMCID: PMCPMC3534767.

31. Schwebke JR, Richey CM, Weiss HL. Correlation of behaviors with microbiological changes in vaginal flora. J Infect Dis. 1999;180(5):1632-6. https://doi.org/10.1086/315065 Epub 1999/10/09. PubMed PMID: 10515826.

32. Marrazzo JM, Thomas KK, Agnew K, Ringwood K. Prevalence and risks for bacterial vaginosis in women who have sex with women. Sex Transm Dis. 2010;37(5):335-9 Epub 2010/04/30. PubMed PMID: 20429087; PubMed Central PMCID: PMCPMC3291172

33. Gray RH, Wawer MJ, Serwadda D, Kigozi G. The role of male circumcision in the prevention of human papillomavirus and HIV infection. J Infect Dis. 2009;199(1):1-3. https://doi.org/10.1086/595568 Epub 2008/12/18. PubMed PMID: 19086812

34. Price LB, Liu CM, Johnson KE, Aziz M, Lau MK, Bowers J, et al. The effects of circumcision on the penis microbiome. PLoS One. 2010;5(1):e8422.

35. Sanchez S, Garcia PJ, Thomas KK, Catlin M, Holmes KK. Intravaginal metronidazole gel versus metronidazole plus nystatin ovules for bacterial vaginosis: a randomized controlled trial. Am J Obstet Gynecol. 2004;191(6): 1898-906. https://doi.org/10.1016/j.ajog.2004.06.089 Epub 2004/12/14. PubMed PMID: 15592270.

36. Swidsinski A, Doerffel Y, Loening-Baucke V, Swidsinski S, Verstraelen H, Vaneechoutte M, et al. Gardnerella biofilm involves females and males and is transmitted sexually. Gynecol Obstet Investig. 2010;70(4):256-63. https:// doi.org/10.1159/000314015 Epub 2010/11/06. PubMed PMID: 21051845.

37. Balashov SV, Mordechai E, Adelson ME, Gygax SE. Identification, quantification and subtyping of Gardnerella vaginalis in noncultured clinical vaginal samples by quantitative PCR. J Med Microbiol. 2014;63(Pt 2):162-75. https://doi.org/10. 1099/jmm.0.066407-0 Epub 2013/11/10. PubMed PMID: 24200640

38. Gardner HL, Dukes CD. Haemophilus vaginalis vaginitis: a newly defined specific infection previously classified non-specific vaginitis. Am J Obstet Gynecol. 1955;69(5):962-76 Epub 1955/05/01. PubMed PMID: 14361525.

39. Zozaya M, Ferris MJ, Siren JD, Lillis R, Myers L, Nsuami MJ, et al. Bacterial communities in penile skin, male urethra, and vaginas of heterosexual couples with and without bacterial vaginosis. Microbiome. 2016;4:16. https://doi.org/10.1186/s40168-016-0161-6 Epub 2016/04/20. PubMed PMID: 27090518; PubMed Central PMCID: PMCPMC4835890.
40. Nelson DE, Dong Q, Van der Pol B, Toh E, Fan B, Katz BP, et al. Bacterial communities of the coronal sulcus and distal urethra of adolescent males. PLoS One. 2012;7(5):e36298. https://doi.org/10.1371/journal.pone.0036298 PubMed PMID: 22606251; PubMed Central PMCID: PMC3350528.

41. Nelson DE, Van Der Pol B, Dong Q, Revanna KV, Fan B, Easwaran S, et al. Characteristic male urine microbiomes associate with asymptomatic sexually transmitted infection. PLoS One. 2010;5(11):e14116. https://doi.org/10.1371/ journal.pone.0014116 Epub 2010/12/03. PubMed PMID: 21124791.

42. Marrazzo JM, Antonio M, Agnew K, Hillier SL. Distribution of genital lactobacillus strains shared by female sex partners. J Infect Dis. 2009;199(5): 680-3. https://doi.org/10.1086/596632 Epub 2009/02/10. PubMed PMID: 19199538; PubMed Central PMCID: PMC3291173.

43. Liu CM, Hungate BA, Tobian AA, Ravel J, Prodger JL, Serwadda D, et al. Penile Microbiota and Female Partner Bacterial Vaginosis in Rakai, Uganda. MBio. 2015;6(3):e00589. https://doi.org/10.1128/mBio.00589-15 PubMed PMID: 26081632; PubMed Central PMCID: PMCPMC4471566.

44. Zozaya-Hinchliffe M, Lillis R, Ferris M, Taylor S, Martin DH. Carriage of bacterial vaginosis-associated species by male sexual partners. American Society of Microbiology 108th General Meeting; 2008.

45. Eren AM, Zozaya M, Taylor CM, Dowd SE, Martin DH, Ferris MJ. Exploring the diversity of Gardnerella vaginalis in the genitourinary tract microbiota of monogamous couples through subtle nucleotide variation. PLoS One. 2011;6(10):e26732. https://doi.org/10.1371/journal. pone.0026732 Epub 2011/11/03. PubMed PMID: 22046340; PubMed Central PMCID: PMCPMC3201972.

46. Mandar R, Punab M, Borovkova N, Lapp E, Kiiker R, Korrovits P, et al. Complementary seminovaginal microbiome in couples. Res Microbiol. 2015;166(5): 440-7. https://doi.org/10.1016/.j.resmic.2015.03.009 PubMed PMID: 25869222.

47. Marrazzo JM, Koutsky LA, Eschenbach DA, Agnew K, Stine K, Hillier SL. Characterization of vaginal flora and bacterial vaginosis in women who have sex with women. J Infect Dis. 2002;185(9):1307-13. https://doi.org/10. 1086/339884 Epub 2002/05/10. PubMed PMID: 12001048.

48. Berger BJ, Kolton S, Zenilman JM, Cummings MC, Feldman J, McCormack WM. Bacterial vaginosis in lesbians: a sexually transmitted disease. Clin Infect Dis. 1995;21(6):1402-5 Epub 1995/12/01. PubMed PMID: 8749623.

49. Aral SO, Leichliter JS, Blanchard JF. Overview: the role of emergent properties of complex systems in the epidemiology and prevention of sexually transmitted infections including HIV infection. Sex Transm Infect. 2010;86(Suppl 3):iii1-3. https://doi.org/10.1136/sti.2010.047373 Epub 2010/12/01. 86/Suppl_3/iii1. PubMed PMID: 21098053.

50. Morris M, Goodreau S, Moody J. Sexual networks, concurrency and STD/HIV. In: Holmes KK, editor. Sexually transmitted diseases. 4th ed. New York: McGraw-Hill Medical; 2008. p. xxv-2166.

51. Kenyon C, Delva W. It's the network, stupid: a population's sexual network connectivity determines. F1000Res. 2018. https:/f1000research.com/articles/ 7-1880/v1.

52. Potterat JJ, Zimmerman-Rogers H, Muth SQ, Rothenberg RB, Green DL, Taylor JE, et al. Chlamydia transmission: concurrency, reproduction number, and the epidemic trajectory. Am J Epidemiol. 1999;150(12):1331-9 Epub 1999/12/22. PubMed PMID: 10604776.

53. Morris M, Kretzschmar M. Concurrent partnerships and the spread of HIV. AIDS. 1997;11(5):641-8 Epub 1997/04/01. PubMed PMID: 9108946.

54. Watts $\mathrm{CH}$, May RM. The influence of concurrent partnerships on the dynamics of HIV/AIDS. Math Biosci. 1992;108(1):89-104 Epub 1992/02/01. PubMed PMID: 1551000.

55. Maughan-Brown B, Kenyon C, Lurie MN. Partner age differences and concurrency in South Africa: implications for HIV-infection risk among young women. AIDS Behav. 2014;18(12):2469-76. https://doi.org/10.1007/s10461-014-0828-6

56. Laumann EO, Youm Y. Racial/ethnic group differences in the prevalence of sexually transmitted diseases in the United States: a network explanation. Sex Transm Dis. 1999;26(5):250-61 Epub 1999/05/20. PubMed PMID: 10333277.

57. Kraut-Becher J, Eisenberg M, Voytek C, Brown T, Metzger DS, Aral S. Examining racial disparities in HIV: lessons from sexually transmitted infections research. J Acquir Immune Defic Syndr. 2008;47(Suppl 1):S20-7. https://doi.org/10.1097/ QAl.0b013e3181605b95 Epub 2008/04/09. PubMed PMID: 18301130.

58. Kenyon CR, Buyze J, Klebanoff M, Brotman RM. Association between bacterial vaginosis and partner concurrency: a longitudinal study. Sex Transm Infect. 2016. https://doi.org/10.1136/sextrans-2016-052652 PubMed PMID: 27645157.

59. Ghani AC, Swinton J, Garnett GP. The role of sexual partnership networks in the epidemiology of gonorrhea. Sex Transm Dis. 1997;24(1):45-56 Epub 1997/01/01. PubMed PMID: 9018783. 
60. Koumans EH, Farley TA, Gibson JJ, Langley C, Ross MW, McFarlane M, et al. Characteristics of persons with syphilis in areas of persisting syphilis in the United States: sustained transmission associated with concurrent partnerships. Sex Transm Dis. 2001;28(9):497-503 Epub 2001/08/24. PubMed PMID: 11518865.

61. Kenyon CR, Tsoumanis A, Schwartz IS, Maughan-Brown B. Partner concurrency and HIV infection risk in South Africa. Int J Infect Dis. 2016;45: 81-7. https://doi.org/10.1016/j.jij.2016.03.001 PubMed PMID: 26955757.

62. Aral SO, Padian NS, Holmes KK. Advances in multilevel approaches to understanding the epidemiology and prevention of sexually transmitted infections and HIV: an overview. J Infect Dis. 2005;191(Suppl 1):S1-6. https:// doi.org/10.1086/425290 Epub 2005/01/01. PubMed PMID: 15627219.

63. Sawers L, Stillwaggon E. Concurrent sexual partnerships do not explain the HIV epidemics in Africa: a systematic review of the evidence. J Int AIDS Soc. 2010;13:34. https://doi.org/10.1186/1758-2652-13-34 Epub 2010/09/15. PubMed PMID: 20836882

64. Lagarde E, Auvert B, Carael M, Laourou M, Ferry B, Akam E, et al. Concurrent sexual partnerships and HIV prevalence in five urban communities of subSaharan Africa. AIDS. 2001;15(7):877-84 Epub 2001/06/16. PubMed PMID: 11399960.

65. Kenyon C. Strong associations between national prevalence of various STIS suggests sexual network connectivity is a common underpinning risk factor. BMC Infect Dis. 2017;17(1):682. https://doi.org/10.1186/s12879-017-2794-x Epub 2017/10/14. PubMed PMID: 29025419; PubMed Central PMCID: PMCPMC5639489.

66. Kenyon CR, Buyze J, Klebanoff M, Brotman RM. Incident trichomonas vaginalis is associated with partnership concurrency: a longitudinal cohort study. Sex Transm Dis. 2017;44(11):695-9.

67. Morris M, Kurth AE, Hamilton DT, Moody J, Wakefield S. Concurrent partnerships and HIV prevalence disparities by race: linking science and public health practice. Am J Public Health. 2009;99(6):1023-31 Epub 2009/ 04/18. PubMed PMID: 19372508.

68. Kenyon CR. Bypassing the 'rapid-clearance-in-males-buffer': a fourth mechanism to explain how concurrency enhances STI spread. Int J STD AIDS 2017. https://doi.org/10.1177/0956462417706246 PubMed PMID: 28457203.

69. Van Der Pol B, Williams JA, Orr DP, Batteiger BE, Fortenberry JD. Prevalence, incidence, natural history, and response to treatment of trichomonas vaginalis infection among adolescent women. J Infect Dis. 2005;192(12): 2039-44. https://doi.org/10.1086/498217 Epub 2005/11/17. PubMed PMID: 16288365.

70. Hobbs MM, Seña AC, Swygard H, Schwebke J. Trichomonas vaginalis and trichomoniasis. Sex Transm Dis. 2008;12:771-93.

71. Brotman RM, Bradford LL, Conrad M, Gajer P, Ault K, Peralta L, et al. Association between Trichomonas vaginalis and vaginal bacterial community composition among reproductive-age women. Sex Transm Dis. 2012;39(10):807-12. https://doi.org/10.1097/OLQ.0b013e3182631c79 PubMed PMID: 23007708; PubMed Central PMCID: PMCPMC3458234.

72. Hickey RJ, Zhou X, Pierson JD, Ravel J, Forney LJ. Understanding vaginal microbiome complexity from an ecological perspective. Transl Res. 2012; 160(4):267-82. https://doi.org/10.1016/j.trsl.2012.02.008 PubMed PMID: 22683415; PubMed Central PMCID: PMC3444549.

73. Martin DH, Marrazzo JM. The Vaginal Microbiome: Current Understanding and Future Directions. J Infect Dis. 2016;214(Suppl 1):S36-41. https://doi.org/ 10.1093/infdis/jiw184 Epub 2016/07/28. PubMed PMID: 27449871; PubMed Central PMCID: PMCPMC4957511.

74. Lam MH, Birch DF. Survival of Gardnerella vaginalis in human urine. Am J Clin Pathol. 1991;95(2):234-9 Epub 1991/02/01. PubMed PMID: 1992615.

75. Schwebke JR, Rivers C, Lee J. Prevalence of Gardnerella vaginalis in Male Sexual Partners of Women With and Without Bacterial Vaginosis. Sex Transm Dis. 2009;36(2):92-4. https://doi.org/10.1097/Olq.0b013e3181886727 PubMed PMID: ISI:000262890500008.

76. Fethers KA, Fairley CK, Morton A, Hocking JS, Hopkins C, Kennedy LJ, et al. Early sexual experiences and risk factors for bacterial vaginosis. J Infect Dis. 2009;200(11):1662-70.

77. Koumans EH, Sternberg M, Bruce C, McQuillan G, Kendrick J, Sutton M, et al. The prevalence of bacterial vaginosis in the United States, 2001-2004; associations with symptoms, sexual behaviors, and reproductive health. Sex Transm Dis. 2007;34(11):864-9.

78. Kenyon $C R$, Colebunders $\mathrm{R}$. Strong association between the prevalence of bacterial vaginosis and male point-concurrency. Eur J Obstet Gynecol Reprod Biol. 2014;172:93-6. https://doi.org/10.1016/j.ejogrb.2013.10.011 PubMed PMID: 24183351.
79. Muzny CA, Schwebke JR. Pathogenesis of Bacterial Vaginosis: Discussion of Current Hypotheses. J Infect Dis. 2016;214(Suppl 1):S1-5. https://doi.org/10. 1093/infdis/jiw121 Epub 2016/07/28. PubMed PMID: 27449868; PubMed Central PMCID: PMCPMC4957507.

80. Kenyon C, Colebunders R, Crucitti T. The global epidemiology of bacterial vaginosis: a systematic review. Am J Obstet Gynecol. 2013;209(6):505-23. https://doi.org/10.1016/j.ajog.2013.05.006 PubMed PMID: 23659989.

81. Kenyon C, Osbak K. Sexual networks, HIV, race and bacterial vaginosis. AIDS. 2015;29(5):641-2. https://doi.org/10.1097/QAD.0000000000000566 Epub 2015/02/25. PubMed PMID: 25710290.

82. Hickey RJ, Zhou X, Settles ML, Erb J, Malone K, Hansmann MA, et al. Vaginal microbiota of adolescent girls prior to the onset of menarche resemble those of reproductive-age women. MBio. 2015;6(2). https://doi.org/10.1128/mBio. 00097-15 PubMed PMID: 25805726; PubMed Central PMCID: PMCPMC4453513.

83. Jespers V, Hardy L, Buyze J, Loos J, Buve A, Crucitti T. Association of Sexual Debut in adolescents with microbiota and inflammatory markers. Obstet Gynecol. 2016;128(1):22-31. https://doi.org/10.1097/AOG.0000000000001468 Epub 2016/06/09. PubMed PMID: 27275789

84. Klebanoff MA, Andrews WW, Zhang J, Brotman RM, Nansel TR, Yu KF, et al. Race of male sex partners and occurrence of bacterial vaginosis. Sex Transm Dis. 2010;37(3):184.

85. Zhou X, Hansmann MA, Davis CC, Suzuki H, Brown CJ, Schutte U, et al. The vaginal bacterial communities of Japanese women resemble those of women in other racial groups. FEMS Immunol Med Microbiol. 2010;58(2): 169-81. https://doi.org/10.1111/j.1574-695X.2009.00618.x Epub 2009/11/17. PubMed PMID: 19912342; PubMed Central PMCID: PMCPMC2868947.

86. Aral SO, Over M, Manhart L, Holmes KK. Sexually Transmitted Infections. In: Jamison DT, Mosley WH, editors. Disease control priorities in developing countries: health policy responses to epidemiological change. 2. Washington (DC): World Bank; 2006. p. 653-89.

87. Kenyon CR, Osbak K, Tsoumanis A. The Global Epidemiology of Syphilis in the Past Century - A Systematic Review Based on Antenatal Syphilis Prevalence. PLoS Negl Trop Dis. 2016;10(5):e0004711. https://doi.org/10. 1371/journal.pntd.0004711 PubMed PMID: 27167068; PubMed Central PMCID: PMCPMC4864207.

88. Kenyon C, Colebunders R, Buyze J. Classification of incidence and prevalence of certain sexually transmitted infections by world regions. Int J of Infec Dis. 2014;18:73-80.

89. Kenyon CR, Tsoumanis A, Osbak K. Strong Country Level Correlation between Syphilis and HSV-2 Prevalence. J Sex Transm Dis. 2016;2016: 5959032. https://doi.org/10.1155/2016/5959032 PubMed PMID: 27069710; PubMed Central PMCID: PMCPMC4812442.

90. Ward H, Ronn M. Contribution of sexually transmitted infections to the sexual transmission of HIV. Curr Opin HIV AIDS. 2010:5(4):305-10. https://doi. org/10.1097/COH.0b013e32833a8844 Epub 2010/06/15. PubMed PMID: 20543605; PubMed Central PMCID: PMC2923028.

91. Cohen CR, Lingappa JR, Baeten JM, Ngayo MO, Spiegel CA, Hong T, et al. Bacterial vaginosis associated with increased risk of female-to-male HIV-1 transmission: a prospective cohort analysis among African couples. PLoS Med. 2012;9(6):e1001251. https://doi.org/10.1371/journal.pmed.1001251 Epub 2012/06/30. PubMed PMID: 22745608; PubMed Central PMCID: PMCPMC3383741.

92. MacManes MD. Promiscuity in mice is associated with increased vaginal bacterial diversity. Naturwissenschaften. 2011;98(11):951.

93. Yildirim S, Yeoman CJ, Janga SC, Thomas SM, Ho M, Leigh SR, et al. Primate vaginal microbiomes exhibit species specificity without universal Lactobacillus dominance. ISME J. 2014;8(12):2431-44. https://doi.org/10. 1038/ismej.2014.90 Epub 2014/07/19. PubMed PMID: 25036926; PubMed Central PMCID: PMCPMC4260710.

94. Kirby D. Changes in sexual behaviour leading to the decline in the prevalence of HIV in Uganda: confirmation from multiple sources of evidence. Sex Transm Dis. 2008;84(Suppl 2):ii35-41.

95. Halperin D, Mugurungi O, Hallett T, Muchini B, Campbell B, Magure T, et al. A surprising prevention success: why did the HIV epidemic decline in Zimbabwe? PLoS Med. 2011;8(2):e1000414. https://doi.org/10.1371/journal. pmed.1000414 Epub 2011/02/25. PubMed PMID: 21346807. 